\title{
Minor differences in sand physicochemistry lead to major differences in bacterial community structure and function after exposure to synthetic acid mine drainage
}

\author{
PJ Welz ${ }_{-}^{a^{*}}, J-B$ Ramond ${ }^{b c}, D A$ Cowan ${ }^{b c}, S G$ Burton $^{a d}, M$ le Roes-Hill ${ }^{a}$ \\ ${ }^{a}$ Biocatalysis and Technical Biology (BTB) Research group, Cape Peninsula University of Technology, \\ Bellville campus, PO box 1906, Bellville, South Africa 7535 \\ ${ }^{b}$ Institute for Microbial Biotechnology and Metagenomics (IMBM), University of the Western Cape, \\ Bellville, South Africa 7535 \\ *Corresponding author. Tel +27-21-9538498; fax +27-21-9538494 \\ E-mail addresses: welzp@cput.ac.za (PJ Welz); jbaptiste.ramond@gmail.com (J-B Ramond); \\ leroesm@cput.ac.za (M le Roes-Hill); don.cowan@up.ac.za (DA Cowan); stephanie.burton@up.ac.za \\ (SG Burton)
}

Present addresses:

${ }^{c}$ Centre for Microbial Ecology and Genomics (CMEG), Department of Genetics, University of Pretoria, Lynwood, Pretoria, South Africa 0002

${ }^{d}$ Research and Postgraduate Education, University of Pretoria, Lynwood, Pretoria, South Africa 0002

\section{Abstract}

The formation of environmentally toxic acidic waste from mining activities is a world-wide problem. Neutralization of this waste can be accomplished by physicochemical and/or biological means. In this short-term study, synthetic acid mine drainage was added to sandfilled mesocosms containing silica-dominated (quartz) sand. Glucose was added as a carbon source for microbial iron and/or sulphate reduction. Replicates contained two separate batches of sand obtained from the same quarry site. The investigations used to assess and compare the chemical and biological functioning of the replicates included system hydraulic conductivity measurements, sand chemistry, effluent chemistry and bacterial community fingerprinting. Minor differences in composition of the sand, including the levels of available nutrients and micronutrients, resulted in major differences in measured parameters. 
Significant differences in effluent chemistry were found in systems containing different batches of sand. It was demonstrated that the characteristics of the sand and the presence of acid mine drainage impacted the bacterial community structure and function. The importance of the physical substrate on the selection of functional microbial communities in systems remediating AMD should not be under-estimated. The physical substrate should be carefully selected and it may be prudent to include small-scale comparative studies in each particular setting prior to full-scale implementation.

\section{Key words}

Acid mine drainage; bacterial community structure; bioremediation; neutralization; sand; sulphate reduction

\section{Introduction}

Acid mine drainage (AMD) emanates from sulphide-rich ores of abandoned mines flooded with groundwater, or mine tailings oxygenated with rainwater [1]. AMD is characterized by a low $\mathrm{pH}$ and high concentrations of sulphate, iron and other dissolved metals [2]. AMD is toxic and presents a major environmental problem in many countries, especially in aquatic environments where, in oxygenated surface waters, a toxic precipitate known as 'yellowboy' is formed by the oxidation of dissolved Fe(II) and hydrolysis of $\mathrm{Fe}(\mathrm{III})$ [3].

Conventional treatment of AMD typically consists of three basic processes which result in the production of calcite-rich sludge: dosing with lime slurry, aeration and flocculation. Many of the latest technologies focus on optimizing these processes to reduce the quantity of sludge production [4]. Systems requiring minimal intervention have been dubbed "passive" treatment systems and include treatment (constructed) wetlands [5-7], permeable reactive barriers [8-9] and other bioreactors designed to enhance microbial sulphate reduction [1012]. Wetland-type systems and permeable reactive barriers may include limestone to aid in the neutralization of AMD through dissolution of carbonates $[6,9]$ but in most passive 
treatment systems, microbial reduction of sulphates to sulphides and the concomitant production of bicarbonate is fundamental to the neutralization of AMD $[5-6,13]$. The subsequent formation of sulphide-metal precipitates is also an important mechanism for the removal of iron and other metals from AMD in passive treatment systems [6].

Biological iron and sulphate reduction relies on the supply of electron donors, usually in the form of an organic substrate such as compost, manure or municipal sludge [6, 12, 14-16]. The degradation of complex materials is performed by microbial consortia, including cellulose-degrading, acetogenic, methanogenic and sulphate reducing bacteria (SRB) $[5,12$, 16-18]. It is therefore difficult to achieve a steady concentration of utilizable, simple substrates for SRB and sulphate reduction may be rate-limited under field conditions, especially when the substrate has high cellulose content [5, 19-20]. In addition, AMD may be characterized by high concentrations of heavy metals which can negatively impact SRB communities [20].

In this study, neutralization of AMD, iron and sulphate reduction, hydraulic properties, carbohydrate utilization patterns and bacterial community structures [monitored by terminalrestriction fragment length polymorphism (T-RFLP)], of six sand-filled experimental mesocosms amended/not amended with synthetic AMD were compared under strictly controlled experimental conditions. Two groups of replicates were included, containing sand low in neutralizing capacity, quarried from the same geographical location but at different times. To prevent variations likely to arise with the use of complex sources of carbon, glucose was included as a defined, non-limiting and consistent source of readily available carbon known to be suitable for sulphate reduction by SRB. The study was not designed to assess the effect of heavy metals on microbial sulphate and/or iron reduction of the treatment of AMD over a protracted period. 


\section{Materials and Methods}

\subsection{Set-up, mode of operation, equilibration and amendment of sand mesocosms}

Six identical mesocosms (length $173 \mathrm{~cm} /$ width $106 \mathrm{~cm}$ ), each containing $\sim 0.5 \mathrm{~m}^{3}$ of river sand with a void volume of $\sim 0.08 \mathrm{~m}^{3}$ and depth of $0.3 \mathrm{~m}$ were set-up and operated in batch mode: influent was drip-fed onto the surface inlet at a rate of $0.68 \mathrm{Lmin}^{-1}$ and allowed to gravitate vertically and longitudinally towards the outlet for the duration of equilibration and experimental periods. The mesocosms were subdivided into 2 groups: group (A)BCD and group EF, each group containing different batches of sand obtained from the same quarry site. Mesocosm A was designated as a control. The mechanical fractions and major elements of each batch are given in Table 1.

When initiating studies using microbial consortia it is important that the microbial communities within experimental replicates are equilibrated (i.e. present similar microbial community structures). It has been found that $\sim 90$ days is a suitable period for equilibration in these systems when fed twice weekly with a basal nutrient solution of $0.3 \mathrm{~g}$ yeast extract (Biolab $^{\circledR}$, Wadeville, Gauteng, RSA cat no: HG000BX6.500) and 0.3 g D (+) glucose (Merck®, Darmstadt, Germany, chemically pure Cat no: SAAR2676020EM), dissolved in 12.5 L tap water [21]. This procedure was therefore applied prior to amendment with AMD. Thereafter, all mesocosms were fed on a weekly basis with the same basal nutrients. In addition, 5 mesocosms (B-F) were amended simultaneously with feeding with highly acidic $(\mathrm{pH}<2)$ synthetic AMD based on that used by Potgieter-Vermaak et al [1] containing 500 $\mathrm{mgL}^{-1}$ magnesium ions $\left(\mathrm{Mg}^{2+}\right), 1500 \mathrm{mgL}^{-1} \mathrm{Fe}(\mathrm{II}), 500 \mathrm{mgL}^{-1} \mathrm{Fe}(\mathrm{III})$ and $6000 \mathrm{mgL}^{-1}$ sulphate ions $\left(\mathrm{SO}_{4}{ }^{-}\right)$. In order to provide sufficient carbon electron donors for the SRB, a high concentration of glucose $\left(8000 \mathrm{mgL}^{-1}\right)$ was also added to the synthetic AMD. The amount of glucose was estimated by using the stoichiometric requirements for total sulphate reduction and doubling this to ensure adequate substrate for both the sulphate-reducing and nonsulphate reducing heterotrophic requirements, according to equation 1 . The COD/sulphate 
Table 1

Physical and elemental characterization of sand before (pre) and after (post) amendment with acid mine drainage

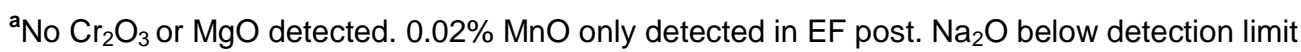

\begin{tabular}{|c|c|c|c|c|c|c|c|}
\hline \multicolumn{8}{|c|}{ Mechanical fraction } \\
\hline & clay & silt & & fine sand & & medium sand & coarse sand \\
\hline BCD pre & $0.4 \%$ & $1.0 \%$ & & $34.4 \%$ & & $24.0 \%$ & $40.2 \%$ \\
\hline EF pre & $2.4 \%$ & $1.0 \%$ & & $36.6 \%$ & & $22.6 \%$ & $37.4 \%$ \\
\hline \multicolumn{8}{|c|}{ Major elements ${ }^{a}$} \\
\hline & $\mathrm{Al}_{2} \mathrm{O}_{3}$ & $\mathrm{CaO}$ & $\mathrm{Fe}_{2} \mathrm{O}_{3}$ & & $\mathrm{~K}_{2} \mathrm{O}$ & $\mathrm{P}_{2} \mathrm{O}_{5}$ & $\mathrm{SiO}_{2}$ \\
\hline BCD pre & $0.82 \%$ & $0.20 \%$ & 0.33 & & $0.02 \%$ & $0.01 \%$ & $96.51 \%$ \\
\hline EF pre & $0.37 \%$ & $0.84 \%$ & 0.17 & & $0.03 \%$ & $0.01 \%$ & $96.59 \%$ \\
\hline$B C D$ post & $0.90 \%$ & $0.30 \%$ & 0.42 & & $0.02 \%$ & $0.01 \%$ & $95.72 \%$ \\
\hline EF post & $0.45 \%$ & $0.61 \%$ & 0.36 & & $0.02 \%$ & $0.01 \%$ & $96.26 \%$ \\
\hline
\end{tabular}


ratio (1.4, wt.wt), was thus considerably higher than suggested by other authors for sulphate reduction $(0.67-1)[6,17,22]$.

$$
\mathrm{C}_{6} \mathrm{H}_{12} \mathrm{O}_{6}+3 \mathrm{SO}_{4}^{2-} \rightarrow 3 \mathrm{H}_{2} \mathrm{~S}+6 \mathrm{HCO}_{3}^{-}
$$

(Equation 1)

\subsection{Sampling procedures}

\subsubsection{Sand samples}

Composite $(3 x)$ core samples were extracted from each mesocosm using a Perspex pipe with an internal diameter of $25 \mathrm{~mm}$ and a rubber bung. Samples from each mesocosm were divided into 4 environmental niches [surface $(0$ to $-3 \mathrm{~cm})$ and deep $(-10$ to $-15 \mathrm{~cm})$ environments at the inlet and the outlet] and thoroughly mixed. Samples taken before and after the experiment were used for bacterial community fingerprinting.

Composite $(3 \mathrm{x})$ samples were also extracted from the centre of each mesocosm before amendment and at the end of the experimental period. The three cores from each of the (A)BCD mesocosms were thoroughly mixed together as were those from group EF. These samples were used to compare changes in the elemental composition and concentration of available micronutrients of the sand before and after amendment with synthetic AMD.

\subsubsection{Effluent samples}

Beginning one hour after feeding/amendment commenced, effluent was collected for an additional hour. The volume of effluent emanating from each mesocosm was recorded (Section 2.3.1) and chemical analyses were performed on the samples (Section 2.5). 


\subsection{Measurement of physical parameters}

\subsubsection{System Hydraulic conductivity (SHC)}

SHC increases with a decrease in biomass and vice versa and is a good indicator of microbial stability/instability [21]. SHC was determined by measuring the volume of effluent emanating from a given mesocosm between one and two hours after the commencement of feeding/amendment $\left[\mathrm{L} / \mathrm{hr}\left(\mathrm{m}^{3} \text { sand }\right)^{-1}\right]$.

\subsection{Analysis of physical substrate (sand)}

\subsubsection{Major element analysis}

Major elements in the sand samples were determined at the Central Analytical Facility at the University of Stellenbosch (Stellenbosch, South Africa) by X-ray fluorescence (XRF) spectrometry on a PANalytical Wavelength Dispersive spectrometer (Almelo, Netherlands) fitted with an Rh tube and a gas-flow proportional counter using an argon (90\%) and methane $(10 \%)$ mixture. Prior to analysis, samples were crushed into a fine powder with a jaw crusher and milled in a tungsten Zib mill after which a fused glass disc was prepared using $10 \mathrm{~g}$ of high purity trace element and REE element free flux $\left(\mathrm{LiBO}_{2}=32.83 \%, \mathrm{Li}_{2} \mathrm{~B}_{4} \mathrm{O}_{7}\right.$ $=66.67 \%$, Lil $=0.50 \%$ ) mixed with $1 \mathrm{~g}$ of sample. Correction for sample matrix effects was performed by applying theoretical alpha factors and measuring line overlap factors to the raw intensities measured with SuperQ PANalytical software. Control standards used for calibration were NIM-G (Granite from the Council for Mineral Technology, South Africa) and BHVO-1 (Basalt from the United States Geological Survey, Reston).

Differences in the elemental and mechanical properties of each sand batch were not significant (Table 1). The most abundant major element detected in both sands was silica (95.72\% and $96.59 \%$ in group BCD and EF, respectively). 


\subsubsection{Determination of mineralogy}

Mineralogy was determined by X-ray diffraction (XRD) at the Department of Geological Sciences at the University of Cape Town (Cape Town, South Africa) using a Philips PW 1390 XRD instrument (Almelo, Netherlands) with a Copper K- $\alpha$ X-Ray tube with X-ray wavelength of $1.542 \mathrm{~A}$, accelerating voltage of $40 \mathrm{kV}$ and current of $5 \mathrm{~mA}$. Bragg $2 \Theta$ angles between 2 and $70^{\circ}$ were used for analysis. A continuous scan step (size $0.02^{\circ}$ and time 0.4 s) was applied. The resultant XRD spectra of 2 theta vs. intensity were input into X'Pert software and the d-spacing of the most intense peaks calculated by solving for the Bragg equation. The dominant mineral was quartz. No aluminosilicates or carbonate minerals were detected.

\subsubsection{Quantification of available micronutrients}

Analysis of available micronutrient elements was performed using a Varian® MPX ICP-OES spectrophotometer (Agilent Technologies, Santa Clara, USA) after extraction according to standard methods [23] at Bemlab (Pty) Ltd. (Strand, South Africa). Mechanical fractions were determined according to standard methods [23].

\subsection{Effluent analysis}

\subsubsection{Redox potential and $\mathrm{pH}$}

The redox potential and $\mathrm{pH}$ of freshly collected samples were determined using a $\mathrm{pH} 700$ meter and relevant probes (Eutech Instruments, Singapore).

\subsubsection{Sulphate $\left(\mathrm{SO}_{4}{ }^{-}\right), \mathrm{Fe}$ (II) and $\mathrm{Fe}$ (III)}

The concentrations of $\mathrm{SO}_{4}{ }^{-}, \mathrm{Fe}$ (II) and $\mathrm{Fe}(\mathrm{III})$ were determined immediately after sample collection using the Merck Spectroquant ${ }^{\circledR}$ test kit for $\mathrm{SO}_{4}{ }^{-}$(Cat no: 1.14791 .000$)$ and Fe (Cat no: 1.00796.0001) and a Merck Spectroquant ${ }^{\circledR}$ Pharo instrument, together with all system (in-built), instrument and reagent controls and standards as stipulated by the manufacturer. 
Samples falling out of range of the assays were diluted timeously and appropriately and the assay repeated.

\subsubsection{Chemical oxygen demand (COD)}

COD concentrations were determined immediately after sample collection using a Merck Spectroquant ${ }^{\circledR}$ Pharo instrument and Merck Spectroquant ${ }^{\circledR}$ cell tests for a range of COD concentrations (cat no: 1.14895.0001, 1.14541.0001 and 1.14691.0001) according to the manufacturer's instructions.

\subsubsection{Identification and quantification of organic substrate (glucose) and metabolites} using high performance liquid chromatography (HPLC)

Organic compounds in the fresh effluent samples were identified and quantified by reverse phase HPLC using a Merck ${ }^{\circledR}$ Hitachi Lachrom instrument and a Phenomenex ${ }^{\circledR}$ (Torrance, USA) Rezex RHM-monosaccharide $\mathrm{H}+(8 \%$ cross-linkage) column according to the method described by La'Zaro et al. (1989). An L-7400 ultraviolet detector $(210 \mathrm{~nm})$ and an Agilent ${ }^{\circledR}$ (Santa Clara, USA) refractive index detector were used for the detection of acids and alcohols, respectively. Where possible, organic molecules were quantified using relevant standard graphs prepared from HPLC chromatograms and identified by spiking selected samples with relevant standard solutions. The theoretical COD and actual COD values of the organic molecules were calculated and used for subsequent mass balance analysis and the compilation of metabolic profiles as previously described [24].

\subsection{Analysis of the microbial community structure}

\subsubsection{Extraction of DNA from composite sand samples}

Total DNA from the mesocosm sand was extracted from $0.5 \mathrm{~g}$ (wet weight) using the Powersoilß DNA isolation kit, MO BIO laboratories (San Diego, USA) according to the manufacturer's instructions. 


\subsubsection{PCR amplification}

All polymerase chain reactions (PCRs) were carried out in a Perkin Elmer Thermocycler (Gene Amp PCR system 6700). Bacterial 16S rRNA genes were amplified using the universal primers E9F (5'-GAGTTTGATCCTGGCTCAG-3') and U1510R (5'GGTTACCTTGTTACGACTT-3'). Each PCR reaction contained 1X PCR buffer, $0.2 \mathrm{U}$ Dream Taq ${ }^{\mathrm{TM}}$ polymerase (Fermentas, USA), $200 \mu \mathrm{M}$ of each dNTP, $0.5 \mu \mathrm{M}$ of each primer, $0.1 \%$ BSA and between 5 and $10 \mathrm{ng}$ of total DNA. PCR amplification was carried out as follows: 4 min at $94^{\circ} \mathrm{C}$ for denaturation; 30 cycles of $30 \mathrm{~s}$ at $94^{\circ} \mathrm{C}, 30 \mathrm{~s}$ annealing at $52^{\circ} \mathrm{C}$ and $105 \mathrm{~s}$ at $72^{\circ} \mathrm{C}$; and a final elongation step of $10 \mathrm{~min}$ at $72^{\circ} \mathrm{C}$. To perform terminal restriction fragment length polymorphism (T-RFLP), the primer E9F was 5'-end FAM ${ }^{\mathrm{TM}}$ labelled and the PCR products were purified using the GFX ${ }^{\mathrm{TM}}$ PCR DNA and gel band purification kit as directed by the supplier (GE Healthcare, UK). Purified PCR products (200 ng) were digested with the restriction enzyme Haelll at $37^{\circ} \mathrm{C}$ for $3 \mathrm{~h}$.

\subsubsection{Terminal- restriction fragment length polymorphism (T-RFLP) analysis}

The microbial community structure was assessed by T-RFLP fingerprinting using the $16 \mathrm{~S}$ rRNA gene as a phylogenetic marker. The precise length of terminal restriction fragments ( $\mathrm{T}$ RFs) was determined by capillary electrophoresis using the Applied Biosystems DNA Sequencer 3130 (Applied Biosystems, Foster City, USA) and according to the molecular weight standard Rox1.1 (with an acceptable error of \pm 1 bp). T-RFLP patterns and quality were analyzed using the freeware PeakScanner ${ }^{\mathrm{TM}}$ (version 1.0) (Applied Biosystems, https://products.appliedbiosystems.com). Peak height was used to characterize each unique T-RF, and valid T-RF peaks (between 35 and $1000 \mathrm{bp)} \mathrm{from} \mathrm{triplicate} \mathrm{T-RFLP} \mathrm{profiles} \mathrm{were}$ identified, compiled and aligned to produce large data matrices using the online software TREX (http://trex.biohpc.org) [25]. T-RFs with intensities lower than $0.5 \%$ may have originated from background interference and were thus excluded from the matrices. Non-metric multidimensional scaling (NMDS) plots were created using Bray-Curtis similarity matrices 
with the software Primer 6 (Primer-E Ltd, UK). Two-dimensional NMDS plots were used, where the distance between points reflects the degree of similarity between the microbial community profiles in the samples.

\section{Results and discussion}

AMD poses an environmental hazard in many countries, including South Africa. There is a drive towards finding cost-effective solutions to this problem and bioremediation presents a feasible option. In this study, the neutralization of AMD, the associated (biological) carbohydrate utilization patterns, the hydraulic properties and the similarities/differences in the microbial community structures in mesocosms containing two different batches of sand were compared before and after exposure to AMD.

\subsection{Characteristics of sand mesocosms before exposure to AMD}

* For reference, we define intra-group similarity as comparisons between mesocosms $B, C$ and $D$ as separate entities or between mesocosms $E$ and $F$ as separate entities. Inter-group similarity is defined as comparisons between group BCD mesocosms as a whole with group EF mesocosms as a whole.

\subsubsection{Physicochemical characteristics of sand}

The sand used to construct the mesocosms was obtained from the same quarry site in two separate batches. Sand mesocosms designated A, B, C and D contained sand from one batch and those designated $\mathrm{E}$ and $\mathrm{F}$ contained sand from a second batch. Experimental systems were grouped (group BCD and group EF), based on sand batch.

\subsubsection{Mineralogy}

In soil/sand environments, the primary substrate-dependent physicochemical processes responsible for increasing the $\mathrm{pH}$ of $\mathrm{AMD}$ are dependent on the rapid dissolution of carbonates and/or the slow dissolution of aluminosilicates [26-28]. In this study, no 
carbonate (e.g. calcite, siderite) or aluminosilicate-based minerals were identified in any of the sand samples. Dissolution of sand constituents was thus not expected to play a significant role in the neutralization of AMD in the experimental mesocosms.

\subsubsection{Available nutrients and micronutrients}

Different concentrations of available nutrients and micronutrients were detected in each batch of sand, with available Fe and $\mathrm{K}$ being significantly higher and $\mathrm{Zn}$ significantly lower in the EF sand in comparison to the BCD sand (Fig. 1). It is suggested that these nutrients/micronutrients played a role in the selection of microbial communities in the mesocosms (Section 3.2).

\subsubsection{Redox and $\mathrm{pH}$}

There were no inter-group differences in the effluent redox potential (Fig. 2). The $\mathrm{pH}$ of the effluent from the group EF mesocosms was slightly more alkaline $(7.65 \pm 0.21)$ than that from the group BCD mesocosms (7.13 \pm 0.15$)$ (Fig. 3).

\subsubsection{Analysis of the pre-amendment bacterial community structure}

Bacterial community structures were analysed using T-RFLP and are presented in the form of 2D NMDS plots with low $(<0.1) 2 \mathrm{D}$-stress values (Fig. 4) [29]. The plots provide a visual representation of the similarity (\%) in the communities from each mesocosm (including the control mesocosm) in four experimental niches [inlet, outlet: surface $(0$ to $-3 \mathrm{~cm})$, deep $(-10$ to $-15 \mathrm{~cm})]$.

When comparing the bacterial community structures prior to amendment with AMD [(triangles and circles designated (0) in Fig. 4], it was found that there were significant intragroup, but not inter-group similarities. The intra-group similarity in the surface and deep sediments, respectively of the control (A) and mesocosms B, C and D was $70 \%$ and $40 \%$ and that of mesocosms $E$ and $F$, containing a different batch of sand, $70 \%$ and $80 \%$. In 
$\square \mathrm{Fe} \otimes \mathrm{P} \square \mathrm{K}$
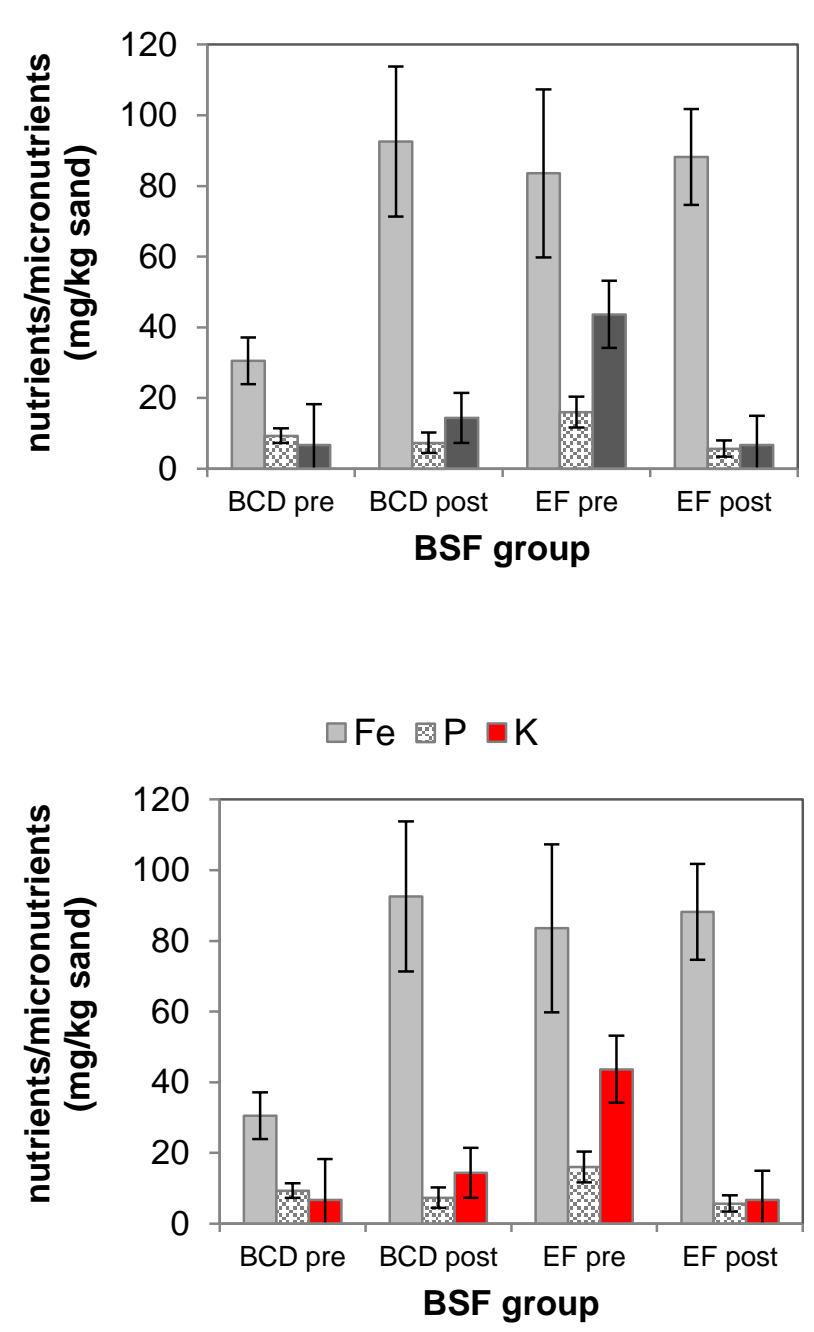

$\square \mathrm{Cu} \otimes \mathrm{Zn} \square \mathrm{Mn} \mathbf{\mathrm { B }}$

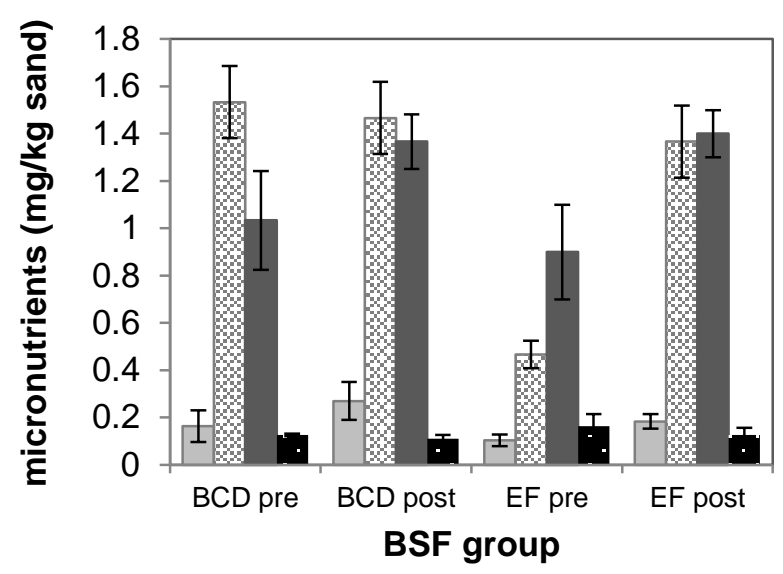

$\square \mathrm{Cu} \otimes \mathrm{Zn} \square \mathrm{Mn} \square \mathrm{B}$

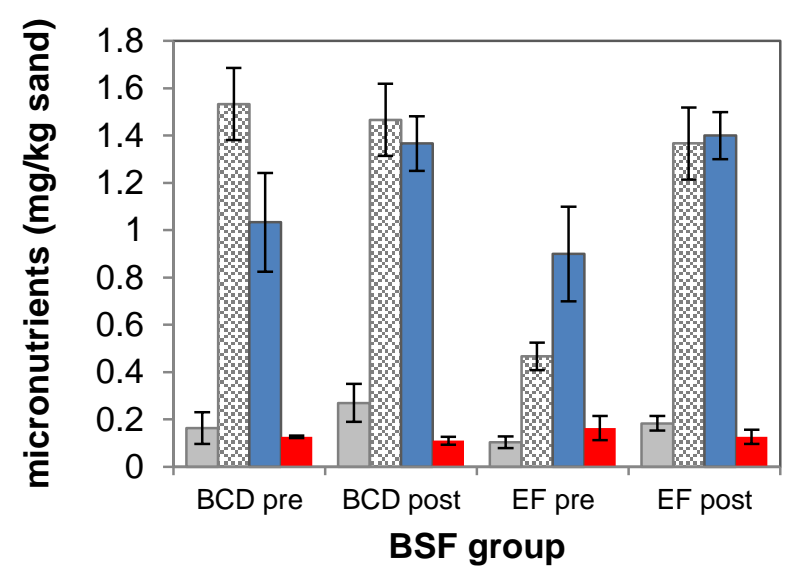

Fig. 1 Available nutrients/micronutrients in the sediment from group BCD and group EF before (pre) and after (post) amendment with acid mine drainage 

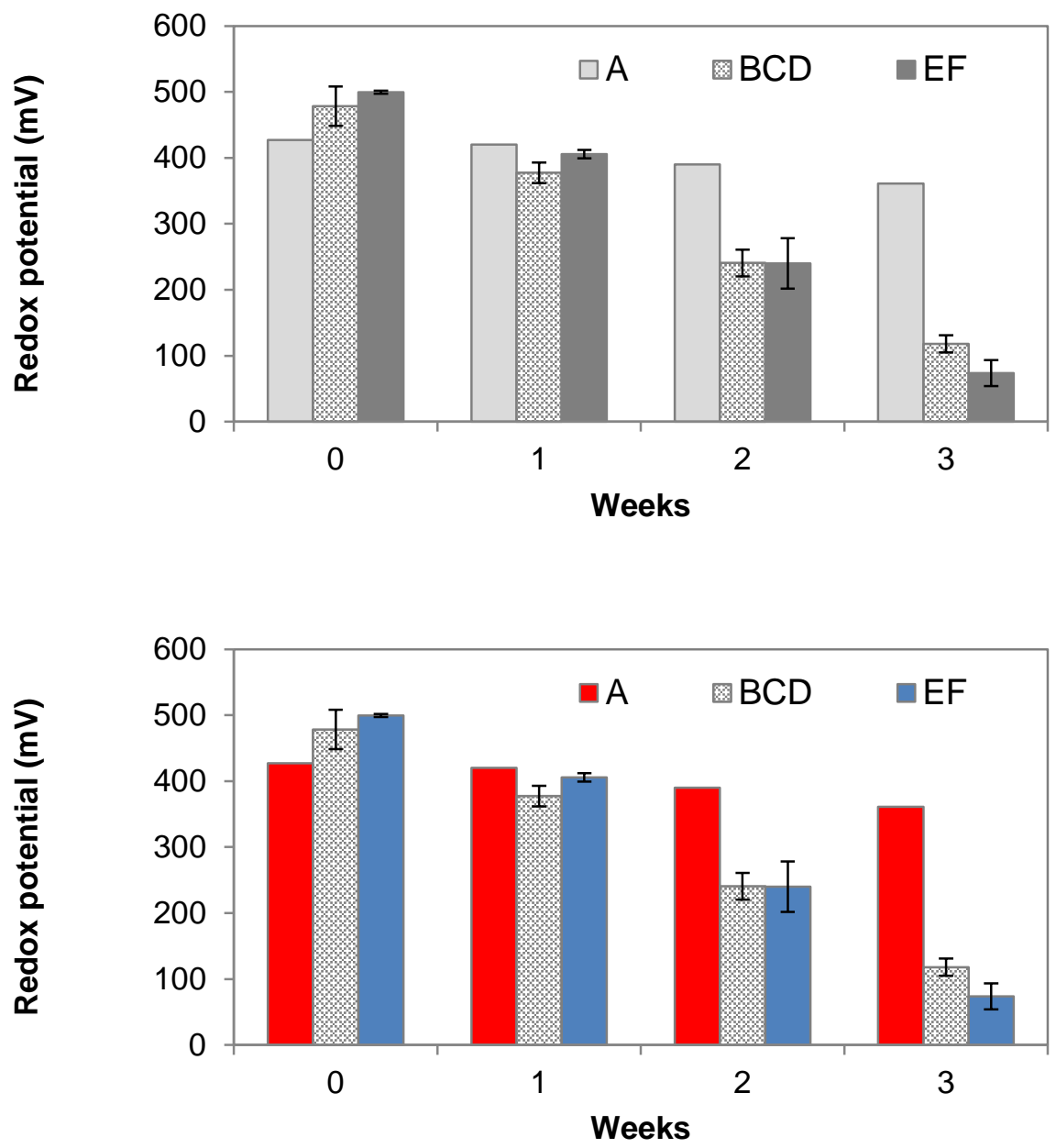

Fig. 2 Redox potential in the effluent from group BCD and group EF before (week 0 ) and during (weeks 1, 2, 3) amendment with acid mine drainage 
a

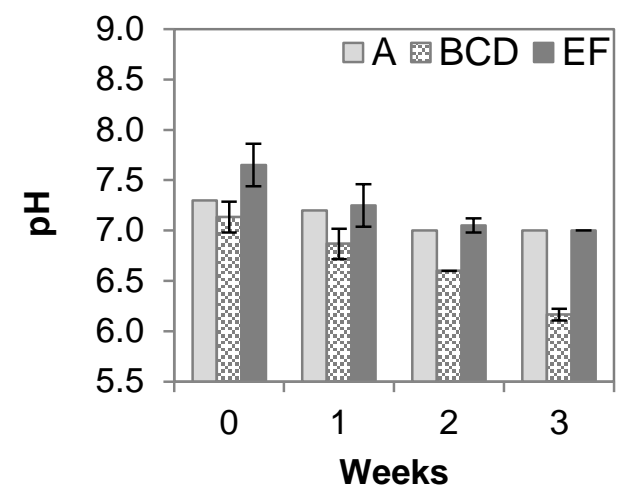

b

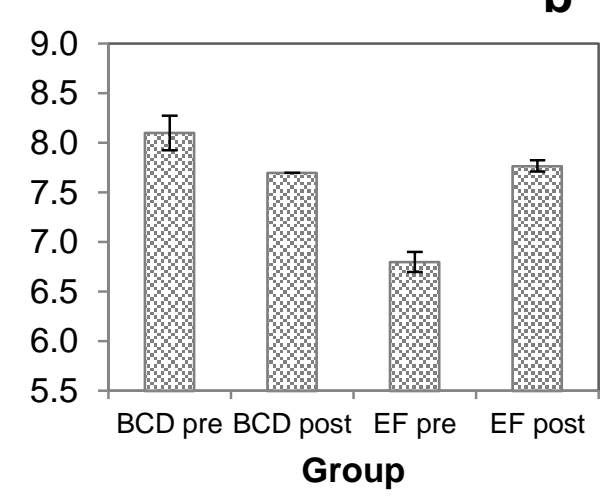

a
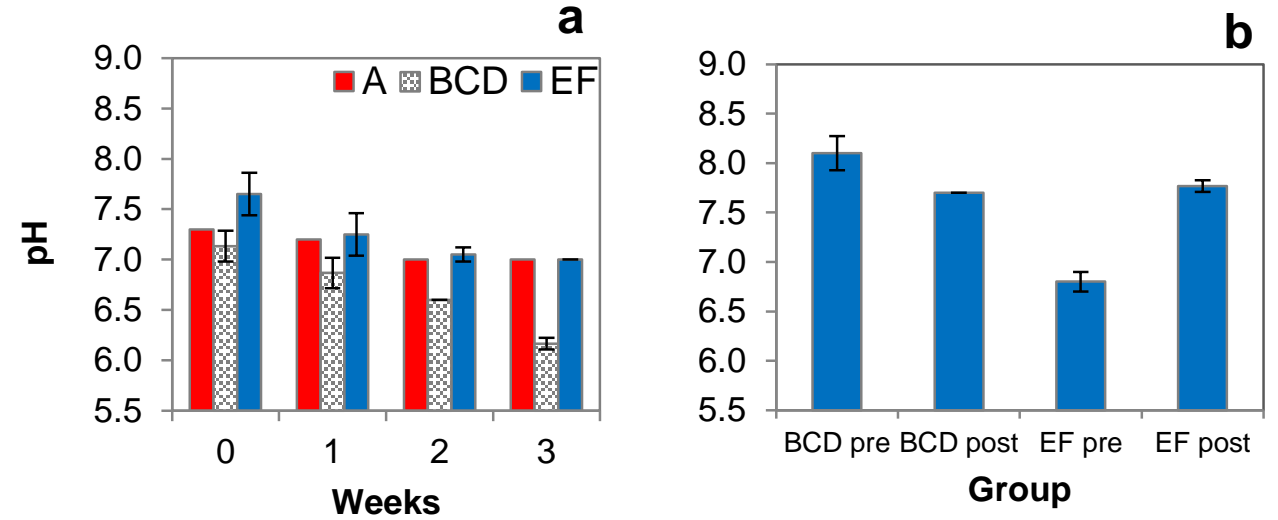

Fig. $3 \mathrm{pH}$ in the effluent (A) and in the sediment (B) from group BCD and group EF before (week 0 , pre), during (weeks $1,2,3$ ) and after (post) amendment with acid mine drainage 

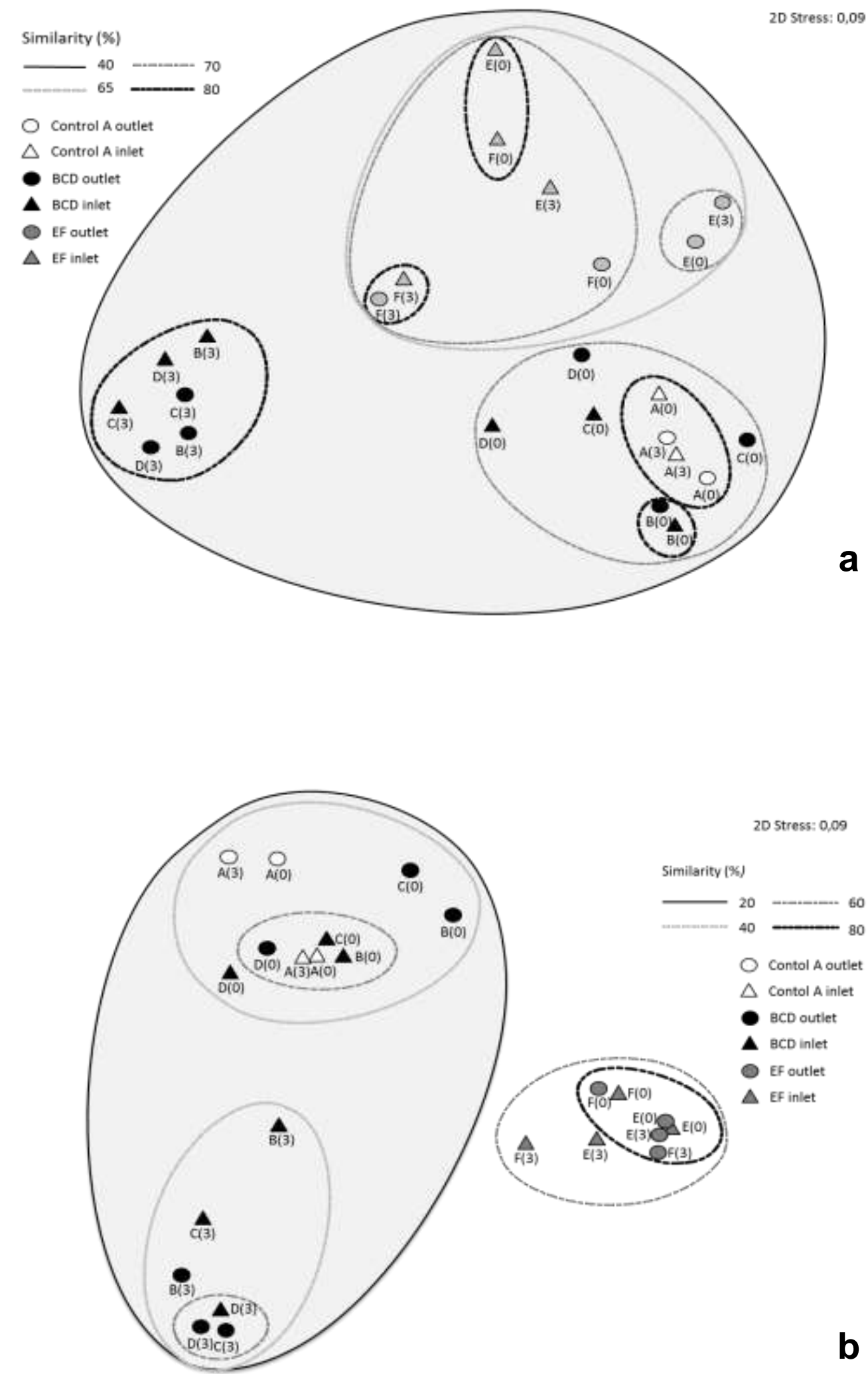

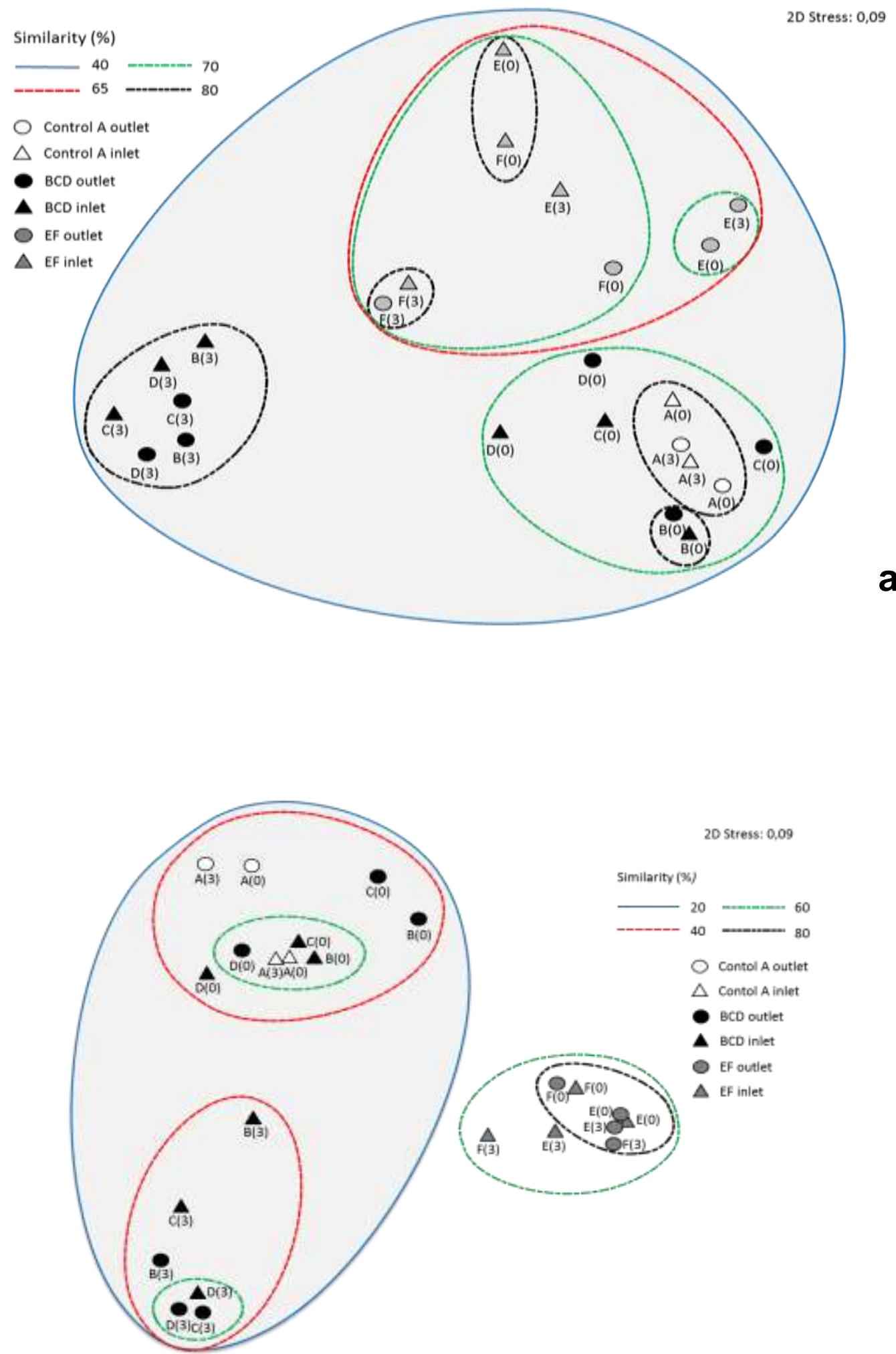

b

Fig. 4 2D MDS plots depicting the similarity between the bacterial $16 \mathrm{~S}$ community structures in the surface (A) and deep (B) sediment samples before (0) and after (3) amendment with AMD 
contrast, the inter-group similarity of groups BCD and EF was only $40 \%$ and $\leq 20 \%$ in the surface and deep sediments, respectively. These results showed that (i) the sand batch was an important determinant of bacterial community composition prior to amendment with AMD, (ii) the 90 day equilibration period was sufficient to establish similar intra-group bacterial communities, despite differences in previous chemical exposure [24, 30-31] and (iii) minor physicochemical differences (Section 3.1.1) in the sand had a significant influence on the bacterial community structure.

\subsubsection{Hydraulic properties}

A large disparity in the system hydraulic conductivity (SHC) was observed during the equilibration period, with the SHC of group BCD being lower than that of group EF (Fig . 5). It has been shown that the hydraulic conductivity in wetlands increases with increased particle size, decreases as uniformity of particle size increases, and is more uniform in saturated sands [32-33]. Difference in particle size was discounted as the primary basis for the disparities in SHC because, apart from the fact that each sand batch was highly similar, group EF sand particles were slightly smaller than group BCD [ $2 \%$ more clay, $2.2 \%$ more fine sand, $2.6 \%$ less medium sand and $2.8 \%$ less coarse sand, but the SHC of group BCD was lower than that of group EF. There were significant differences in the microbial community structure related to sand-batch (Section 3.1.2). It is therefore suggested that that the disparities in SHC were primarily related to biological clogging as previously described $[24,34-35]$

\subsection{Characteristics of sand mesocosms after exposure to AMD}

\subsubsection{Physicochemical characteristics of sand}

There were no significant differences in the elemental composition of either sand batch associated with exposure to AMD. Amendment with AMD caused an expected increase in available Fe in each batch of sand, so that after 3 weeks, similar amounts ( $90 \mathrm{mg} / \mathrm{kg}$ sand) 

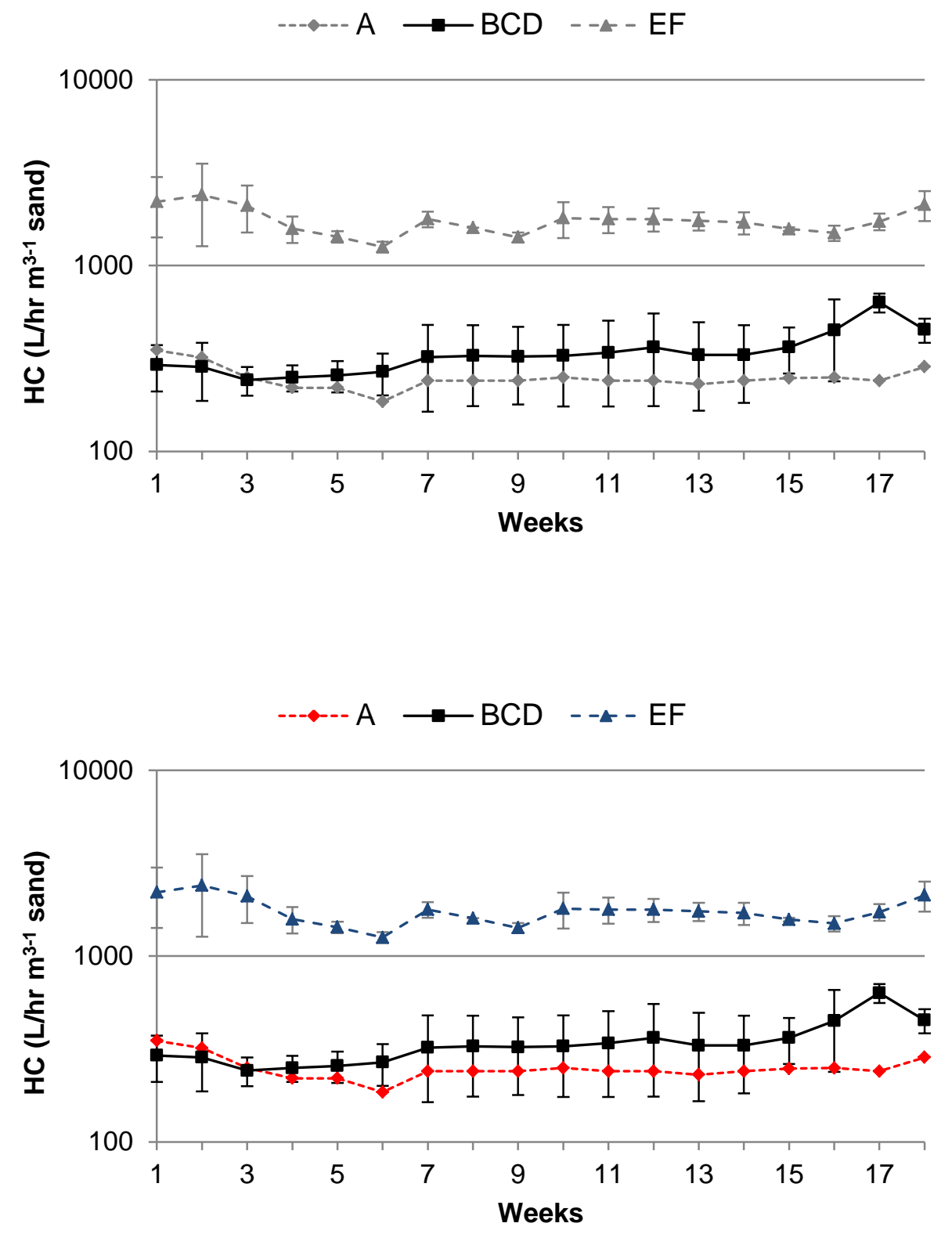

Fig. 5 System hydraulic conductivity (SHC) measurements taken from the control A, group BCD and group EF over the equilibration, experimental and recovery periods (weeks 1-13, 14-16 and 17-18, respectively) 
were measured in group BCD and EF (Fig. 1). The increase was marked ( $50 \mathrm{mg} / \mathrm{kg}$ sand) in the group BCD sand and subtle $(<10 \mathrm{mg} / \mathrm{kg}$ sand) in the group EF sand, demonstrating that Fe from the AMD accumulated preferentially in the Group BCD mesocosms.

\subsubsection{Analysis of the bacterial community structures after exposure to AMD}

After 3 weeks exposure to AMD [triangles and circles designated (3) in Fig. 4], the intergroup similarity of group BCD and EF remained low at $40 \%$ (surface sediments) and $\leq 20 \%$ (deep sediments). The intra-group similarity remained high ( $80 \%$ and $40 \%$ between mesocosms $\mathrm{B}, \mathrm{C}$ and $\mathrm{D}$ and $70 \%$ and $60 \%$ between mesocosms $\mathrm{E}$ and $\mathrm{F}$ in the surface and deep samples, respectively).

Comparison of similarity patterns obtained from before and after amendment with AMD [triangles and circles designated (0) compared with those designated (3) in Fig. 4] indicated that the AMD had a significant impact on the bacterial communities in group BCD mesocosms. In these mesocosms, the pre-amendment communities only displayed $40 \%$ (surface) and $20 \%$ (deep) similarity with the post-amendment communities. By comparison, the impact of $A M D$ on the bacterial communities in group $E$ and $F$ mesocoms was significantly lower, with $80 \%$ (surface) and $60 \%$ (deep) similarity between pre- and postamendment bacterial community structures.

These results clearly demonstrate that the sand batch and exposure to synthetic AMD both had significant effects on the group BCD bacterial community structure. However, the effect of the physical substrate (sand) on the group EF community structure was considerably more pronounced than the effect of AMD.

It has previously been shown that the microtopography, surface composition, surface charge and hydrophobicity of mineral particles play important roles in microbial colonization, biofilm formation and microbial community development [36-37]. However, it has also been shown that microbial communities in AMD-impacted environments are primarily influenced by the 
presence of AMD [3]. This study demonstrated that the relative contributions of the physical substrate and AMD to the evolution of the bacterial communities are not always consistent.

\subsubsection{Neutralization of AMD in sand mesocosms}

In the environment, the three most important processes that buffer AMD are: (i) abiotic dissolution of carbonate materials, which generates alkalinity and consumes protons, (ii) abiotic and microbial reduction of iron oxides and (oxy)hydroxides, and (iii) microbial sulphate reduction [4-5, 14-15]. Bioremediation systems harness one or more of these mechanisms, in particular bacterial sulphate reduction, to detoxify AMD.

In this study, highly acidic synthetic AMD $(\mathrm{pH}<2)$ was neutralized in all 5 sand-filled mesocosms (B-F). Average effluent $\mathrm{pH}$ values differed between group $\mathrm{BCD}$ and $\mathrm{EF}$ (Fig. 3a). Although there was a steady temporal decline in effluent $\mathrm{pH}$, near neutral values of 6.2 \pm 0.1 and $7.0 \pm 0$ were still obtained from group BCD and EF, respectively at week 3 (Fig. 3a). Different inter-group trends in the physical substrate (sand) $\mathrm{pH}$ measurements were also noted (Fig. 3b): In group EF, the $\mathrm{pH}$ increased by close to one unit, while that of group $\mathrm{BCD}$ decreased slightly during the experimental period. However, the final $\mathrm{pH}$ of the sand was similar in both groups. Substrate dissolution was discounted as a major neutralization mechanism (Section 3.1.1).

Despite a high influent concentration of sulphate $\left(6000 \mathrm{mgL}^{-1}\right)$, only negligible concentrations were detected in the effluent of all mesocosms at week 1 (Fig. 6a). In previous studies, a similar effect was seen, where plug flow forced the existing water in the substrate through the outlet, essentially creating a lag in the emergence of effluent and resulting in an anomalously low concentration of influent chemicals being detected after the first amendment with wastewater (Welz et al., 2011).

In group BCD mesocosms, no dissolved sulphate removal occurred during week 2 and only $33 \%$ removal took place during week 3 (Fig. $6 a$ ). In contrast, $86 \%$ and $82 \%$ dissolved 

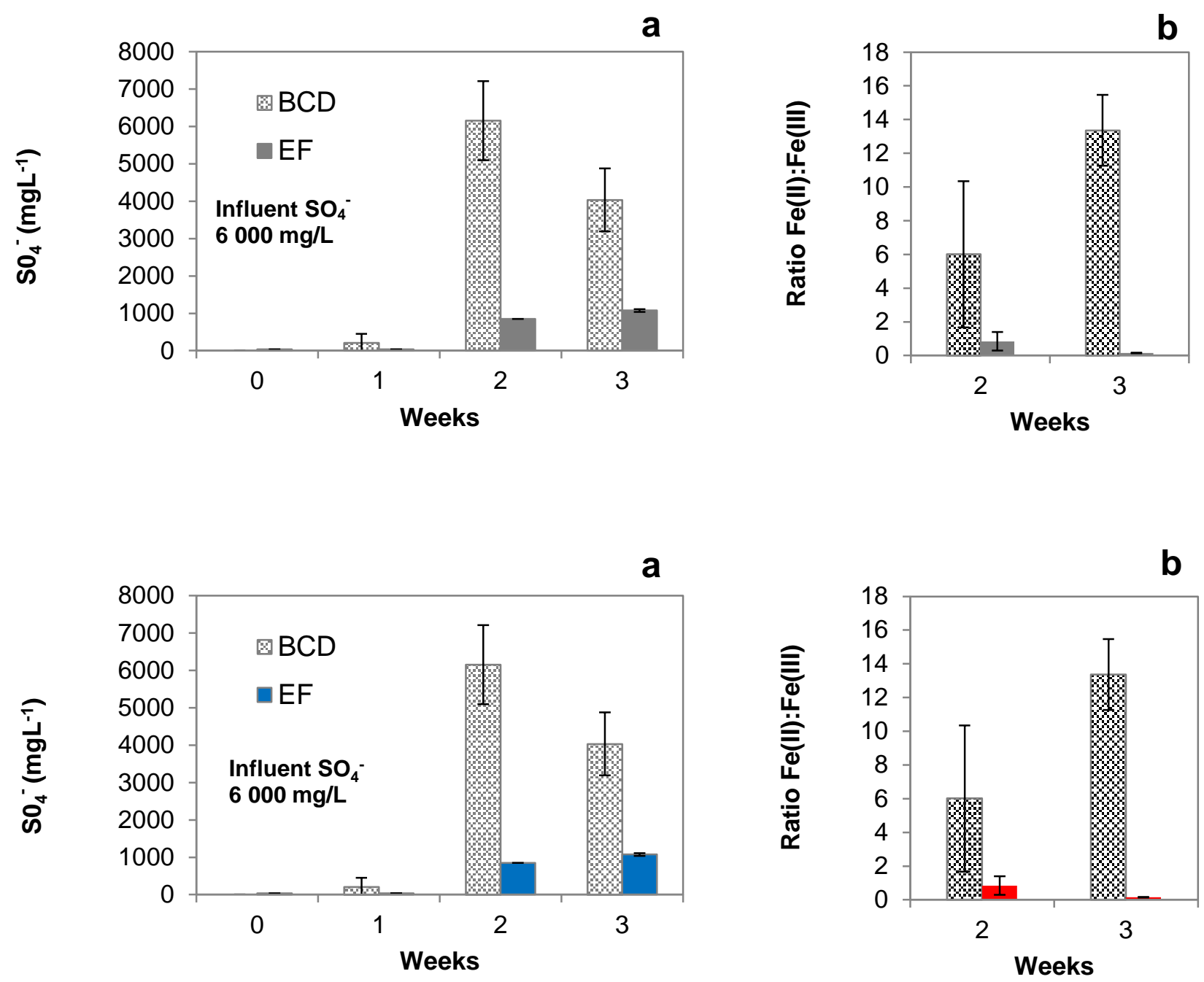

Fig. 6 Effluent sulphate concentration (A) and $\mathrm{Fe}$ (II):Fe(III) ratio (B) from group BCD and group EF before (week 0 ) and after amendment with acid mine drainage (weeks 1, 2, 3) 
sulphate removal was achieved in group EF mesocosms in weeks 2 and 3, respectively, strongly suggesting the functional evolution of sulphate reduction capacity (Fig. 6a). The sulphate-reducing and neutralizing capacity of group EF mesocosms was superior to that of group BCD despite the consistently lower average nominal hydraulic retention time (HRT) (HRT group EF =1.9 days; HRT group BCD 11.1 days). There are two possible explanations for this finding: (i) the original bacterial communities in group EF were inherently more resilient to the presence of AMD and/or (ii) the combination of batch operating mode and low HRT minimized exposure of the bacterial communities, particularly the SRB, to the toxicity of AMD. This is supported by the fact that the impact of AMD on the pre-amendment bacterial communities in group EF was significantly lower than the impact on the group BCD communities (Section 3.2.2).

Due to the "lag" factor, only small amounts of Fe were detected in the effluent during week 1 (data not shown). From week 2, the ratio of $\mathrm{Fe}(\mathrm{II})$ to $\mathrm{Fe}(\mathrm{III})$ measured in the effluent was considerably higher in group BCD than group EF replicates (Fig. 6b). These results suggest that abiotic and/or microbial iron reduction was enhanced in the group BCD mesocosms in comparison with the group EF systems.

\subsubsection{Carbohydrate metabolism}

In a real-world setting, locally available, cheap sources of carbon wastes are typically used as electron donors. However, these carbon sources do not provide a chemically consistent flow of electron donors. This adds complexity to the interpretation of experimental results. In this study, a simple source of carbon was used to limit temporal and spatial variation between replicates. To ensure that sulphate reduction was not rate limited by lack of a readily available carbon source, the stoichiometric COD:sulphate ratio applied (1.4) was higher than previously suggested for microbial sulphate reduction $(0.67$ to 1$)[6,17]$. The ratio of 0.67 is a theoretical value which does not take into account other carbon-dependent metabolic processes and it has been demonstrated that sulphate reduction can be increased 
with larger COD to sulphate ratios [22]. The utilization of the carbon source (glucose) was monitored by quantifying organic metabolites in the effluent and by measuring effluent COD. The glucose utilization patterns were related to sulphate and iron reduction (Fig. 7).

There was a temporal increase in readily biodegradable substrates, mostly volatile fatty acids (Fig. 7) as well as residual glucose measured in the effluent from group BCD mesocosms and average effluent COD concentrations reached approximately $3.5 \mathrm{gL}^{-1}$ by week 3 (Fig. 7). In contrast, only negligible amounts of substrates and metabolites were detected in the effluent from group EF mesocosms, with average effluent COD concentrations of approximately $0.4 \mathrm{gL}^{-1}$ by week 3 (Fig. 7). This substantiates the hypothesis that microbial iron reduction dominated in the group BCD mesocosms. The results are consistent with the fact that the organic carbon requirement for microbial sulphate reduction is substantially higher than that for microbial iron reduction [39].

\subsection{Conclusion}

Each environment, whether natural or artificial, has a unique set of interrelated physicochemical and biological properties and the composition of the physical substrate can have substantial effects on the bacterial community composition and functionality. In this study, subtle differences in the physical substrate (sand) led to significant differences in microbial community composition and consequent biogeochemical processes in sand mesocosms amended with AMD. The physical substrate and the influent AMD had similarly significant effects on the bacterial community structure in three sand-filled mesocosms, while in additional replicates containing a different batch of sand from the same quarry site, the effect of the physical substrate was more pronounced. The importance of the physical substrate on the selection of functional microbial communities in systems remediating AMD should therefore not be under-estimated. In treatment systems relying on microbiological processes, the physical substrate should be carefully selected and it may be prudent to 
a

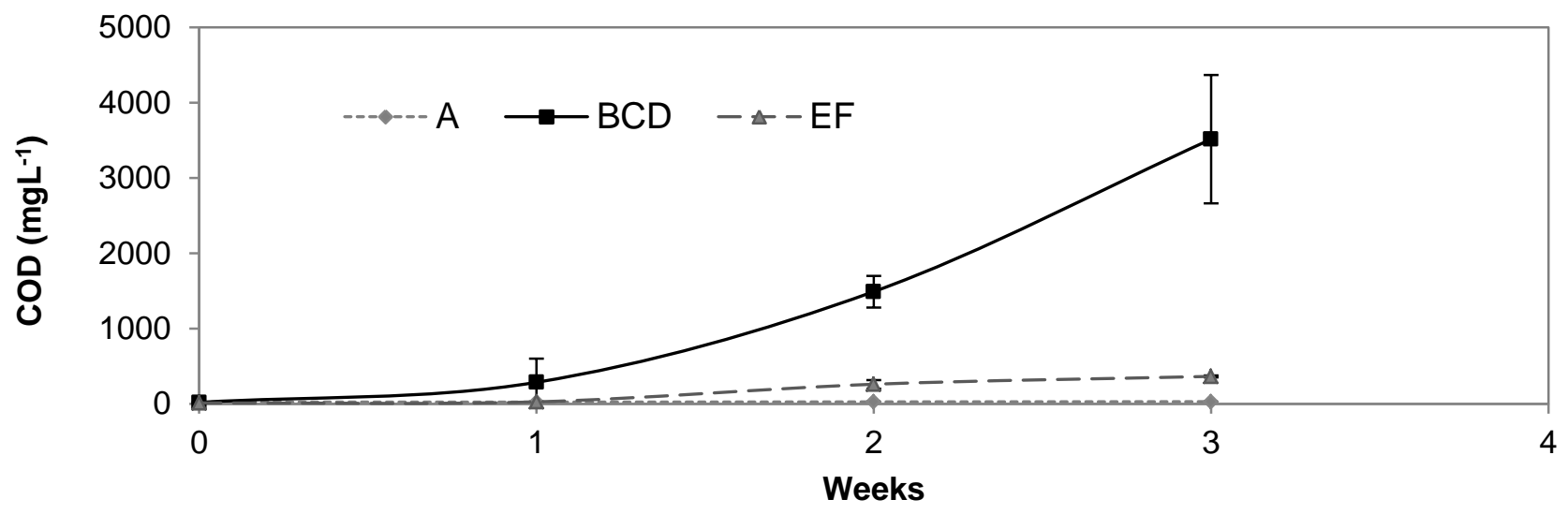

b

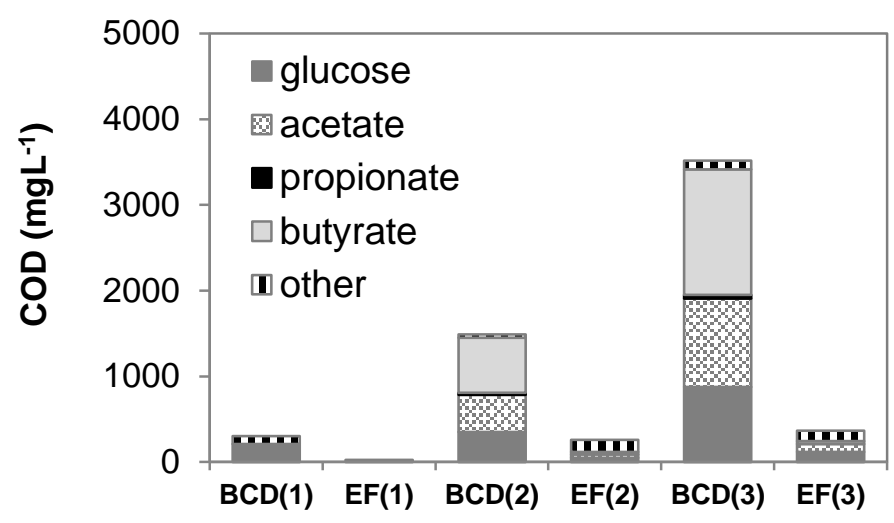

PTS group (week 1,2,3)

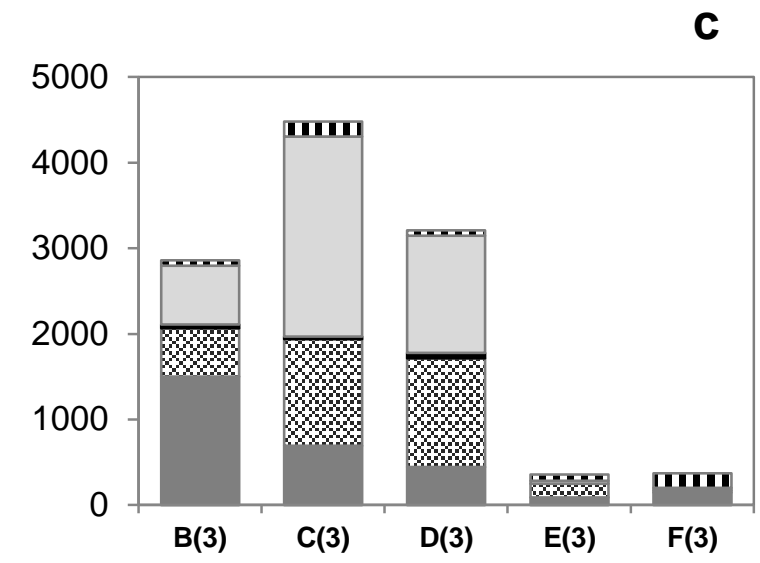

PTS (week 3) 
a

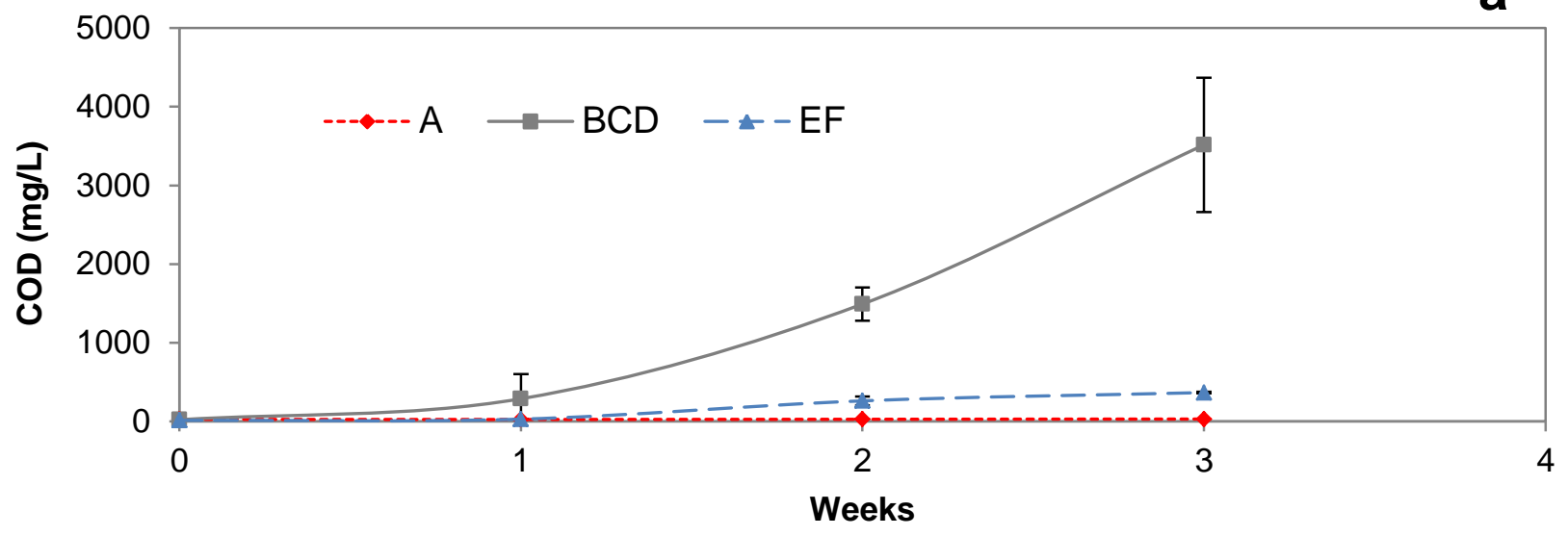

b
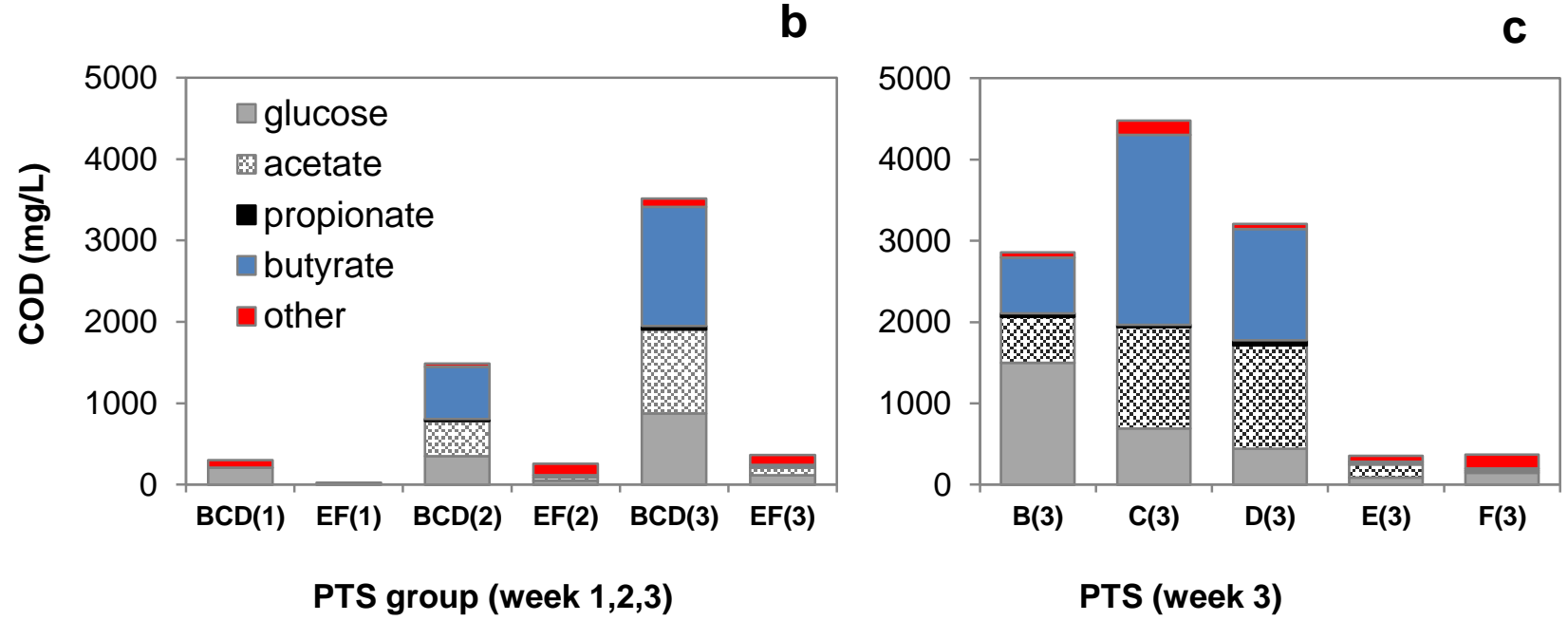

Fig. 7 Total COD concentrations measured in the effluent from the control and group BCD and EF (A); Effluent substrate/metabolite profile from group BCD and EF from week 1-3 (B); Effluent susbstrate/metabolite profiles from individual mesocosms from week 3 (C) 
include small-scale comparative studies in each particular setting prior to full-scale implementation.

\section{Acknowledgements}

We would like to thank the Water Research Commission and the Cape Peninsula University of Technology for funding this project. We would also like to thank the National Research Foundation of South Africa for providing a free-standing bursary to Dr J-B. Ramond.

\section{References}

[1] Potgieter-Vermaak, S.S., J.H. Potgieter, P. Monama, and R. Van Grieken (2006) Comparison of limestone, dolomite and fly ash as pre-treatment agents for acid mine drainage. Miner. Eng. 19: 454-462

[2] Ritcey, G.M. (2005) Tailing management in gold plants. Hydrometall. 78: 477-495

[3] Senko, J.M., P. Wanjugi, M. Lucas, M.A. Bruns, and W.D. Burgos (2008)

Characterization of $\mathrm{Fe}(\mathrm{II})$ oxidizing bacterial activities and communities at two acidic Appalachian coalmine drainage-impacted sites. ISME j. 2: 1134-1145

[4] Kalin, M., A. Fyson, and W.N. Wheeler (2006) The chemistry of conventional and alternative treatment systems for the neutralization of acid mine drainage. Sci. Total. Environ. 366: 395-408

[5] Mayes, W.M., L.C. Batty, P.L. Younger, A.P. Jarvis, M. Koiv, C. Vohla, and U. Mander (2009) Wetland treatment at extremes of pH: A review. Sci. Total. Environ. 407: 3944-3957

[6] Reifler, R.G., J. Krohn, B. Stuart, and C. Socotch (2008) Role of sulfur-reducing bacteria in a wetland system treating acid mine drainage. Sci. Total. Environ. 394: 222-229

[7] Whitehead, P.G., B.J. Cosby, and H. Prior (2005) The Wheal Jane wetlands model for bioremediation of acid mine drainage. Sci. Total. Environ. 338: 125-135. 
[8] Bartzas, G. and K. Komnitsas (2010) Solid phase studies and geochemical modelling of low-cost permeable reactive barriers. J. Hazard. Mater. 183: 301-308

[9] Gilbert, O., T. Rotting, J.L. Cortina, J. de Pablo, C. Ayora, J.L. Carrera, and J. Bolzicco (2011) In-situ remediation of acid mine drainage using a permeable reactive barrier in Aznalcollar (Sw Spain). J. Hazard. Mater. 191: 287-295

[10] Choudhary, R.P., and A.S. Sheoran ( 2012) Performance of single substrate in sulphate reducing bioreactor for the treatment of acid mine drainage. Miner. Eng. 39: 29-35

[11] Song, H., G-J. Yim, S-W. Ji , C.M. Neculita, and T. Hwang (2012) Pilot-scale passive bioreactors for the treatment of acid mine drainage: efficiency of mushroom compost vs. mixed substrates for metal removal. J. Environ. Manag. 111: 150-158

[12] Sheoran, A.S., V. Sheoran, and R.P. Choudary RP (2012) Bioremediaiton of acid-rock drainage by sulphate-reducing prokaryotes: A review. Miner. Eng. 23: 1073-1100

[13] Woulds, C., and B.T. Ngwenya (2004) Geochemical processes governing the performance of a constructed wetland treating acid mine drainage, Central Scotland. Appl. Geochem. 19: 1773-1783

[14] Bilgin, A.A., J. Silverstein, and M. Hernandez (2005) Effects of soluble ferri-hydroxide complexes on microbial neutralization of acid mine drainage. Environ. Sci. Technol. 39: $7826-7832$

[15] Lovley, D.R., and E.J.P. Phillips (1988) Novel mode of microbial energy metabolism: organic carbon oxidation coupled to dissimilatory reduction of iron or manganese. Appl. Environ. Microbiol. 54: 1472-1480

[16] Matthies, R., A.C. Aplin, A.J. Boyce, and A.P. Jarvis (2012) Geochemical and stable isotopic constraints on the generation and passive treatment of acidic, $\mathrm{Fe}-\mathrm{SO}_{4}$ rich waters. Sci Total. Environ. 420: 238-249 
[17] Mulopo, J., H. Greben, J. Sigama, V. Radebe, M. Mashengo, and L. Burke (2011) The relationship between sulphate reduction and COD/VFA utilization using grass cellulose as carbon and energy sources. Appl. Biochem. Biotechnol. 163: 393-403

[18] Wijekoon, K.C., C. Visvanathan, and A. Abeynayaka (2011) Effect of organic loading rate on VFA production, organic matter removal and microbial activity of a two-stage thermophilic anaerobic membrane bioreactor. Bioresour. Technol. 102: 5353-5360

[19] Logan, M.V., K.F. Reardon, L.A. Figueroa, J.E.T. McLain, and D.M. Ahmann (2005) Microbial community activities during establishment, performance and decline of benchscale passive treatment systems. Water Res. 39: 4537-4551

[20] Utigar, V.P., S.M. Harmon, N. Chaudhary, H.H. Tabak, R. Govind, and J.R. Haines (2002) Inhibition of sulfate-reducing bacteria by metal sulfide formation in bioremediation of acid mine drainage. Environ. Toxicol. 17: 40-48

[21] Ramond, J-B., P.J. Welz, D.A. Cowan, and S.G.Burton (2012) Microbial community structure stability, a key parameter in monitoring the development of constructed wetland mesocosms during start-up. Res. Microbiol. 163: 28-35

[22] Rodriguez, R.P., G.H.D. Oliveira, I.M. Raimundi, and M. Zaiat (2012) Assessment of a UASB reactor for the removal of sulfate from acid mine water. Int. Biodeterior. Biodegrad. 74: $48-53$

[23] The non-affiliated soil analysis working committee (1990) Handbook of standard soil methods for advisory purposes. Soil Science Society of South Africa, Pretoria.

[24] Welz, P.J., J-B. Ramond, A. Prins, D.A. Cowan, and S.G.Burton (2011) Ethanol degradation and the benefits of incremental priming in pilot-scale constructed wetlands. Ecol. Eng. 37: 1453-1460 
[25] Culman, S.W., R. Bukowski, H.G. Gauch, H. Cadillo-Quiroz, and D.H. Buckley ( 2009) T-REX: Software for the processing and analysis of T-RFLP data. BMC Bioinforma. 10: 171

[26] Jambor, J.L., J.E. Dutrizac, L.A. Groat, and M. Raudsepp (2002) Static test of neutralization potential of silicate and aluminosilicate minerals. Environ. Geol. 43: 1-17

[27] Miller, S.D., W.S. Stewart, Y. Rusdinar, R.E. Schumann, J.M. Ciccarelli, J. Li, and R. St. C Smart (2010) Methods for estimation of long-term non-carbonate neutralization of acid rock drainage. Sci. Total Environ. 408: 2129-2135

[28] Sherlock, E.J, R.W. Lawrence, and R. Poulin (1995) On the neutralization of acid rock drainage by carbonate and silicate minerals. Environ. Geol. 25: 43-54

[29] Clarke, K. (1993) Non-parametric multivariate analysis of changes in community structure. Aust. J. Ecol. 18: 117-143

[30] Rodriguez Caballaro, A., J-B. Ramond, P.J. Welz, D.A. Cowan, M. Odlare, and S.G. Burton (2012) Treatment of high ethanol concentration wastewater in biological sand filters: enhanced COD removal and bacterial community dynamics. J. Environ. Manag. 109: 54-60

[31] Welz, P.J., J-B. Ramond, D.A. Cowan, and S.G. Burton (2012) Phenolic removal processes in biological sand filters, sand columns and microcosms. Bioresour. Technol. 119: 262-269

[32] Giraldi, D., M. de'Michieli Vitturi, M. Zaramella, A. Marion, and R. lannelli (2009) Hydrodynamics of vertical subsurface flow constructed wetlands: Tracer tests with rhodamine WT amd numerical modelling. Ecol. Eng. 35: 265-273

[33] Suliman, F., C. Futsaether, U. Oxaal, L.E. Haugen, and P. Jenssen (2006) Effect of the inlet-outlet positions on the hydraulic performance of horizontal subsurface-flow constructed wetlands with heterogenous porous media. J. Contam. Hydrol. 87: 22-36 
[34] Molle, P., A. Lienard, A. Grasmick, and A. Iwema (2006) Effect of reeds and feeding operations on hydraulic vertical flow constructed wetlands under hydraulic overloads. Water Res. 40: 606-612

[35] Serrano, L., D. de la Vargo, I. Ruiz, and M. Soto (2010) Winery wastewater treatment in a hybrid constructed wetland. Ecol. Eng. 37: 744-753

[36] Carson, C.V., C. Francesca, C. Allessio, B. Cecilia, and T. Luigi (2009) Biological treatment of heavy metals contaminated waters. Chem. Eng. Trans. 17: 203-208

[37] Gadd, G.M. (2010) Metals, minerals and microbes: geomicrobiology and bioremediation. Microbiol. 156: 609-643

[38] Morrison, M.I., and A.C. Aplin (2009) Redox geochemistry in organic-rich sediments of a constructed wetlands treating colliery spoil leachate. Appl. Geochem. 24: 44-51

[39] Chapelle, F.H., P.M. Bradley, M.A. Thomas, and P.B. McMahon (2009) Distinguishing iron reducing from sulphate reducing conditions. Ground Water 47: 300-305 